\title{
Direct nanoscale observations of the coupled dissolution of calcite and dolomite and the precipitation of gypsum
}

\author{
Francesco G. Offeddu ${ }^{* 1}$, Jordi Cama ${ }^{1}$, Josep M. Soler ${ }^{1}$ and Christine V. Putnis ${ }^{2}$
}

\section{Full Research Paper}

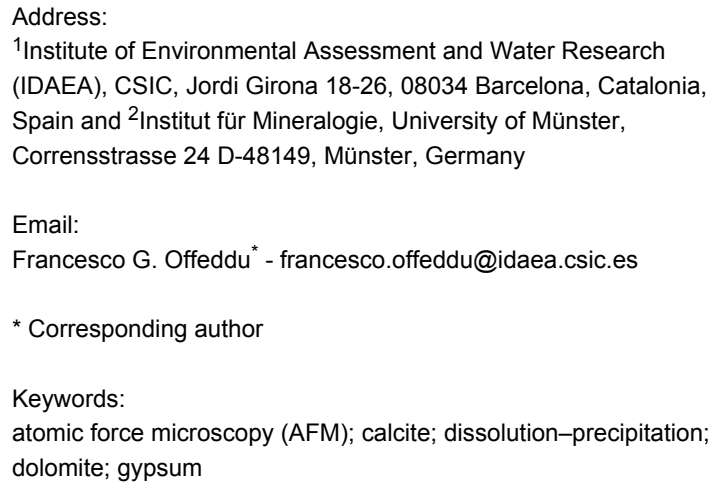

Beilstein J. Nanotechnol. 2014, 5, 1245-1253.

doi:10.3762/bjnano.5.138

Received: 21 March 2014

Accepted: 21 July 2014

Published: 11 August 2014

This article is part of the Thematic Series "Nanomanipulation and environmental nanotechnology".

Guest Editor: T. Glatzel

(C) 2014 Offeddu et al; licensee Beilstein-Institut. License and terms: see end of document.

\begin{abstract}
In-situ atomic force microscopy (AFM) experiments were performed to study the overall process of dissolution of common carbonate minerals (calcite and dolomite) and precipitation of gypsum in $\mathrm{Na}_{2} \mathrm{SO}_{4}$ and $\mathrm{CaSO}_{4}$ solutions with $\mathrm{pH}$ values ranging from 2 to 6 at room temperature $\left(23 \pm 1{ }^{\circ} \mathrm{C}\right)$. The dissolution of the carbonate minerals took place at the (104) cleavage surfaces in sulfate-rich solutions undersaturated with respect to gypsum, by the formation of characteristic rhombohedral-shaped etch pits. Rounding of the etch pit corners was observed as solutions approached close-to-equilibrium conditions with respect to calcite. The calculated dissolution rates of calcite at $\mathrm{pH} 4.8$ and 5.6 agreed with the values reported in the literature. When using solutions previously equilibrated with respect to gypsum, gypsum precipitation coupled with calcite dissolution showed short gypsum nucleation induction times. The gypsum precipitate quickly coated the calcite surface, forming arrow-like forms parallel to the crystallographic orientations of the calcite etch pits. Gypsum precipitation coupled with dolomite dissolution was slower than that of calcite, indicating the dissolution rate to be the rate-controlling step. The resulting gypsum coating partially covered the surface during the experimental duration of a few hours.
\end{abstract}

\section{Introduction}

The overall process of dissolution of carbonate minerals and precipitation of gypsum is relevant in environmental settings, such as the treatment of acid mine drainage (AMD), geological $\mathrm{CO}_{2}$ sequestration and monument preservation. The use of limestone (calcite) in the treatment of AMD with elevated concentrations of heavy metals and sulfate is common [1-5].

The purpose is to retain metals and neutralize acidity by means of the so-called anoxic limestone drain (ALD) [1-5]. AMD, flowing through benches filled with calcite gravel, dissolves limestone and thereby increases the $\mathrm{Ca}^{2+}$ concentration, alkalinity and $\mathrm{pH}$. Because, in general, AMD contains high concentrations of sulfate and metal ions, the dissolution of calcite initi- 
ates a coupled reaction chain that allows the system to precipitate sulfate as gypsum and metals $\left(\mathrm{Al}^{3+}\right.$ and $\left.\mathrm{Fe}^{3+}\right)$ as hydroxides:

$$
\begin{aligned}
\mathrm{CaCO}_{3}+2 \mathrm{H}^{+} & \rightarrow \mathrm{Ca}^{2+}+2 \mathrm{HCO}_{3}{ }^{-} \\
\mathrm{Ca}^{2+}+\mathrm{SO}_{4}{ }^{2-}+2 \mathrm{H}_{2} \mathrm{O} & \rightarrow \mathrm{CaSO}_{4} \cdot 2 \mathrm{H}_{2} \mathrm{O} \downarrow \\
\mathrm{Me}^{3+}+3 \mathrm{H}_{2} \mathrm{O} & \rightarrow \mathrm{Me}(\mathrm{OH})_{3} \downarrow+3 \mathrm{H}^{+}
\end{aligned}
$$

Such coupled processes, in which the dissolution of one phase produces a supersaturation of another phase in the fluid at the mineral-fluid interface and the new phase can precipitate, are well-documented [6-8].

AMD treatment becomes ineffective as soon as the precipitated hydroxides and/or gypsum fully coat the limestone surface and impede further dissolution of calcite. This mechanism is known as passivation or armoring [3,9-16]. While metal phases tend to precipitate between the calcite grains, gypsum tends to precipitate strongly adhered on the dissolving calcite surface, which is the main mechanism responsible for surface passivation [1417]. This strong attachment of gypsum to the calcite surface results from crystallographic continuity between the two phases, namely "lattice matching" as pointed out by Booth et al. [18] The fact that the crystallographic structure of gypsum and calcite exhibits parallel rows of cations and anions, and the cation-cation spacing for both minerals is $4.99 \AA$ suggests a favourable overgrowth of the gypsum (010) plane on top of a calcite cleavage surface.

In the context of geological $\mathrm{CO}_{2}$ sequestration, the interaction between the acidic sulfate-rich brines and carbonate minerals of the reservoir rock promotes calcite dissolution and gypsum precipitation [18-22]. The effect of acid rain on historical monuments, buildings and statue degradation results from the dissolution of limestone by rain containing dissolved atmospheric $\mathrm{SO}_{2}$ and the subsequent precipitation of gypsum [23-25]. Large amounts of synthetic gypsum can precipitate during industrial processes involving the reaction between calcite and sulfuric acid [26].

The motivation of this study is to learn about the overall process of calcium carbonate mineral (calcite and dolomite) dissolution and gypsum precipitation in acid sulfate solutions at the micro-nanoscale by means of in-situ atomic force microscopy (AFM) experiments. This approach allows for a visualization of the processes occurring at the reacting carbonate surface.

In the literature, many studies deal with carbonate mineral reactivity [27-37]. In particular, the study of calcite dissolution and gypsum precipitation by Booth et al. [18] is relevant for our experimental AFM study as the authors provided SEM and AFM observations (in situ and ex situ) of the overall process of gypsum coating on calcite (causing passivation or armoring) at $\mathrm{pH} 1$ and 2 in mixed $\mathrm{HCl}$ and $\mathrm{Li}_{2} \mathrm{SO}_{4}$ solutions. They reported on i) the reduction of calcite reactivity due to the gypsum coating, ii) the shape of gypsum crystals (rows parallel to the flux) and iii) the relation between anions and cations of the lattices of both calcite and gypsum. It is suggested that the likely match between cations favors the epitaxial overgrowth of the gypsum (010) face on top of the calcite cleavage plane.

In this study we attempt to enhance the current knowledge about the complementary processes of calcite/dolomite dissolution and gypsum precipitation. Two types of solution were used: (1) acid sulfate solution $\left(\mathrm{Na}_{2} \mathrm{SO}_{4}\right)$ undersaturated with respect to gypsum and (2) acid sulfate solution $\left(\mathrm{CaSO}_{4}\right)$ equilibrated with respect to gypsum. The experimental $\mathrm{pH}$ ranged from approximately 2 to 6 and the in-situ AFM experiments were run at ambient temperature $\left(23 \pm 1^{\circ} \mathrm{C}\right)$ and pressure.

\section{Experimental}

The experiments were carried out by using a Digital Instruments (Bruker) Nanoscope III AFM equipped with a fluid cell sealed with an O-ring (50 $\mu \mathrm{L}$ volume), in contact mode using $\mathrm{Si}_{3} \mathrm{~N}_{4}$ tips (Bruker, NP-S20) at room temperature $\left(23 \pm 1{ }^{\circ} \mathrm{C}\right)$. The scanning frequency was about $3 \mathrm{~Hz}$ and the image resolution was of 256 lines per scan, giving an average scan time of one image about every 100 seconds. The scan size ranged from $1 \times 1 \mu \mathrm{m}^{2}$ to $15 \times 15 \mu \mathrm{m}^{2}$. Images were analyzed with WSxM free software [38].

Single fragments of calcite (Iceland Spar, Chihuahua, Mexico) and crystalline dolomite (Eugui, Navarra, Spain) of approximately $4 \times 3 \times 1 \mathrm{~mm}$ (crystal volume $\approx 12 \mathrm{~mm}^{3}$ ) were cleaved immediately prior to experiments and attached to a fixed and oriented Teflon holder with commercial conductive carbon cement (CCC) and mounted in the fluid cell. The cleavage surface of calcite and dolomite is the (104) surface.

Acid solutions were prepared immediately before the experiments by adding the appropriate amounts of reactive analytical grade, $\mathrm{CaSO}_{4} \cdot 2 \mathrm{H}_{2} \mathrm{O}$ (Merck pro analysis) and $\mathrm{Na}_{2} \mathrm{SO}_{4}$ (Grüssing purity 98\%), to Millipore MQ water (resistivity $=18 \mathrm{M} \Omega \cdot \mathrm{cm})($ Table 1$)$. The solution $\mathrm{pH}$ was adjusted to the chosen $\mathrm{pH}$ (approximately from 2 to 6 ) by adding concentrated $\mathrm{H}_{2} \mathrm{SO}_{4}$. Measurements of the $\mathrm{pH}$ were carried out by using a InoLab pH meter, equipped with a WTW Sentix 21 electrode calibrated with an accuracy of $\pm 0.02 \mathrm{pH}$ units. The electrode was calibrated with Crison buffer solutions at $\mathrm{pH} 4$ and 7. The saturation index (SI) with respect to gypsum and 


\begin{tabular}{|lllllllll|}
\hline \multicolumn{2}{|c}{ Table 1: Experimental conditions. } & & & & \\
experiment & substrate & $\mathrm{pH}$ & electrolyte & $\mathrm{Ca}$ inp $[\mathrm{mol} / \mathrm{L}]$ & $\mathrm{Na}_{\text {inp }}[\mathrm{mol} / \mathrm{L}]$ & $\mathrm{SO}_{4 \text { inp }}[\mathrm{mol} / \mathrm{L}]$ & $\mathrm{SI}$ calcite & $\mathrm{SI}$ gypsum \\
\hline cal14 & calcite & 2.23 & $\mathrm{Na}_{2} \mathrm{SO}_{4}$ & - & $5.42 \mathrm{E}-02$ & $3.10 \mathrm{E}-02$ & - & - \\
cal12 & calcite & 2.20 & $\mathrm{Na}_{2} \mathrm{SO}_{4}$ & - & $4.62 \mathrm{E}-02$ & $2.70 \mathrm{E}-02$ & - & - \\
cal9 & calcite & 2.18 & $\mathrm{CaSO}_{4}$ & $1.60 \mathrm{E}-02$ & - & $2.50 \mathrm{E}-02$ & -11.0 & 0.05 \\
cal10 & calcite & 2.18 & $\mathrm{CaSO}_{4}$ & $1.60 \mathrm{E}-02$ & - & $2.50 \mathrm{E}-02$ & -11.0 & 0.05 \\
dol6 & dolomite & 2.11 & $\mathrm{Na}_{2} \mathrm{SO}_{4}$ & - & $1.02 \mathrm{E}-02$ & $1.00 \mathrm{E}-02$ & - & - \\
dol3 & dolomite & 2.11 & $\mathrm{Na}_{2} \mathrm{SO}_{4}$ & - & $2.62 \mathrm{E}-02$ & $1.80 \mathrm{E}-02$ & - & - \\
dol4 & dolomite & 2.18 & $\mathrm{CaSO}_{4}$ & $1.60 \mathrm{E}-02$ & - & $2.50 \mathrm{E}-02$ & -11.0 & 0.05 \\
dol1 & dolomite & 2.14 & $\mathrm{Na}_{2} \mathrm{SO}_{4}$ & - & $5.02 \mathrm{E}-02$ & $3.00 \mathrm{E}-02$ & - & - \\
\hline cal19 & calcite & 3.37 & $\mathrm{Na}_{2} \mathrm{SO}_{4}$ & - & $5.56 \mathrm{E}-02$ & $2.70 \mathrm{E}-02$ & - & - \\
cal8 & calcite & 3.06 & $\mathrm{CaSO}_{4}$ & $1.50 \mathrm{E}-02$ & - & $1.60 \mathrm{E}-02$ & -9.2 & 0.00 \\
cal21 & calcite & 2.92 & $\mathrm{Na}_{2} \mathrm{SO}_{4}$ & - & $1.12 \mathrm{E}-02$ & $6.00 \mathrm{E}-03$ & - & - \\
dol5 & dolomite & 3.00 & $\mathrm{CaSO}_{4}$ & $1.50 \mathrm{E}-02$ & - & $1.60 \mathrm{E}-02$ & -9.2 & 0.00 \\
dol7 & dolomite & 3.00 & $\mathrm{Na}_{2} \mathrm{SO}_{4}$ & - & $2.70 \mathrm{E}-02$ & $1.40 \mathrm{E}-02$ & - & - \\
\hline cal4 & calcite & 4.08 & $\mathrm{CaSO}_{4}$ & $1.50 \mathrm{E}-02$ & - & $1.50 \mathrm{E}-02$ & -7.1 & -0.01 \\
cal2 & calcite & 4.03 & $\mathrm{Na}_{2} \mathrm{SO}_{4}$ & - & $1.12 \mathrm{E}-02$ & $6.00 \mathrm{E}-03$ & - & - \\
\hline cal6 & calcite & 4.80 & $\mathrm{CaSO}_{4}$ & $1.50 \mathrm{E}-02$ & - & $1.50 \mathrm{E}-02$ & -5.7 & -0.02 \\
\hline cal3 & calcite & 5.82 & $\mathrm{CaSO}_{4}$ & $1.50 \mathrm{E}-02$ & - & $1.50 \mathrm{E}-02$ & -3.7 & -0.02 \\
\hline
\end{tabular}

calcite of the input solutions was calculated by using the PhreeqC code and the PhreeqC database [39].

The experimental strategy consisted of three stages. First, prior to each in-situ experiment an in-air image of a selected region of the cleaved surface was taken to examine the initial topography and surface features of interest (flat/rough areas, steps terraces and edges; Figure 1a and Figure 1d). Secondly, after an appropriate region of the cleavage surface was selected, the Millipore MQ water was injected by using a syringe to fill the available volume of the fluid cell containing the sample (ca. $38 \mu \mathrm{L}$ ) and flow over the mineral surface. Renovation of the Millipore MQ water was performed after each sequential image capture (ca. $1.5 \mathrm{~min}$ ) to ensure a similar bulk solution concentration as the reaction took place during the experiment and prevent a saturation of the solution during the reaction (close-to-equilibrium approach). During this stage the calcite dissolution rate, $R_{\mathrm{AFM}}\left(\mathrm{mol} \cdot \mathrm{cm}^{-2} \cdot \mathrm{s}^{-1}\right)$, was obtained from the dissolved volume of calcite created by the etch pits (as described by Urosevic et al. [37]):

$$
\begin{gathered}
R_{\mathrm{AFM}}=\Delta V \cdot N_{\mathrm{pit}} / V_{\mathrm{cal}} \cdot\left(t_{2}-t_{1}\right) \\
\Delta V=\left(w_{2} \cdot u_{2}-w_{1} \cdot u_{1}\right) \cdot h
\end{gathered}
$$

where $\Delta V$ is the increase in dissolved volume of an etch pit between $t_{2}$ and $t_{1}$ in two sequential images, $w, u$ and $h$ are the width, length and depth, respectively, of an etch pit ( $h$ remains constant at ca. $0.3 \mathrm{~nm}$ ), $N_{\text {pit }}$ is the average number of etch pits per $\mathrm{cm}^{2}$, and $V_{\text {cal }}$ is the molar volume of calcite $\left(31.20 \mathrm{~cm}^{3} \cdot \mathrm{mol}^{-1}\right)$. By using sequential images, the pit expansion rate, $R_{\mathrm{S}}\left(\mathrm{nm} \cdot \mathrm{s}^{-1}\right)$, was also calculated from the variation in length of the etch pit sides $(\Delta w$ or $\Delta u)$ over time $\left(R_{\mathrm{S}}=\Delta w /\left(t_{2}-t_{1}\right)\right)$. Likewise, the step velocity, $R_{\mathrm{T}}\left(\mathrm{nm} \cdot \mathrm{s}^{-1}\right)$, was calculated from the increase in terrace width $(\Delta L)$ over time $\left(R_{\mathrm{T}}=\Delta L /\left(t_{2}-t_{1}\right)\right)$. After the conclusion of mineral dissolution in Millipore MQ water, the third stage started as the cell was filled with the chosen sulfate-rich acid solution in order to promote the precipitation of gypsum. During this stage, solution renovation was not allowed. Hence, the solution saturation state approached an equilibrium with respect to the dissolving carbonate mineral.

Micro-Raman analysis was used to identify the newly precipitated sulfate phases on the calcite and dolomite cleavage surfaces. Micro-Raman spectra were obtained by using a dispersive spectrophotometer Jobin-Yvon LabRam HR 800 with $532 \mathrm{~nm}$ light for sample excitation and a CCD detector cooled to $-70{ }^{\circ} \mathrm{C}$. The laser power used was between 0.5 and $4 \mathrm{~mW}$. The spectrophotometer was coupled to an optical microscope Olympus BXFM with $50 \times$ and $100 \times$ objectives. The samples were dried before measurement. 

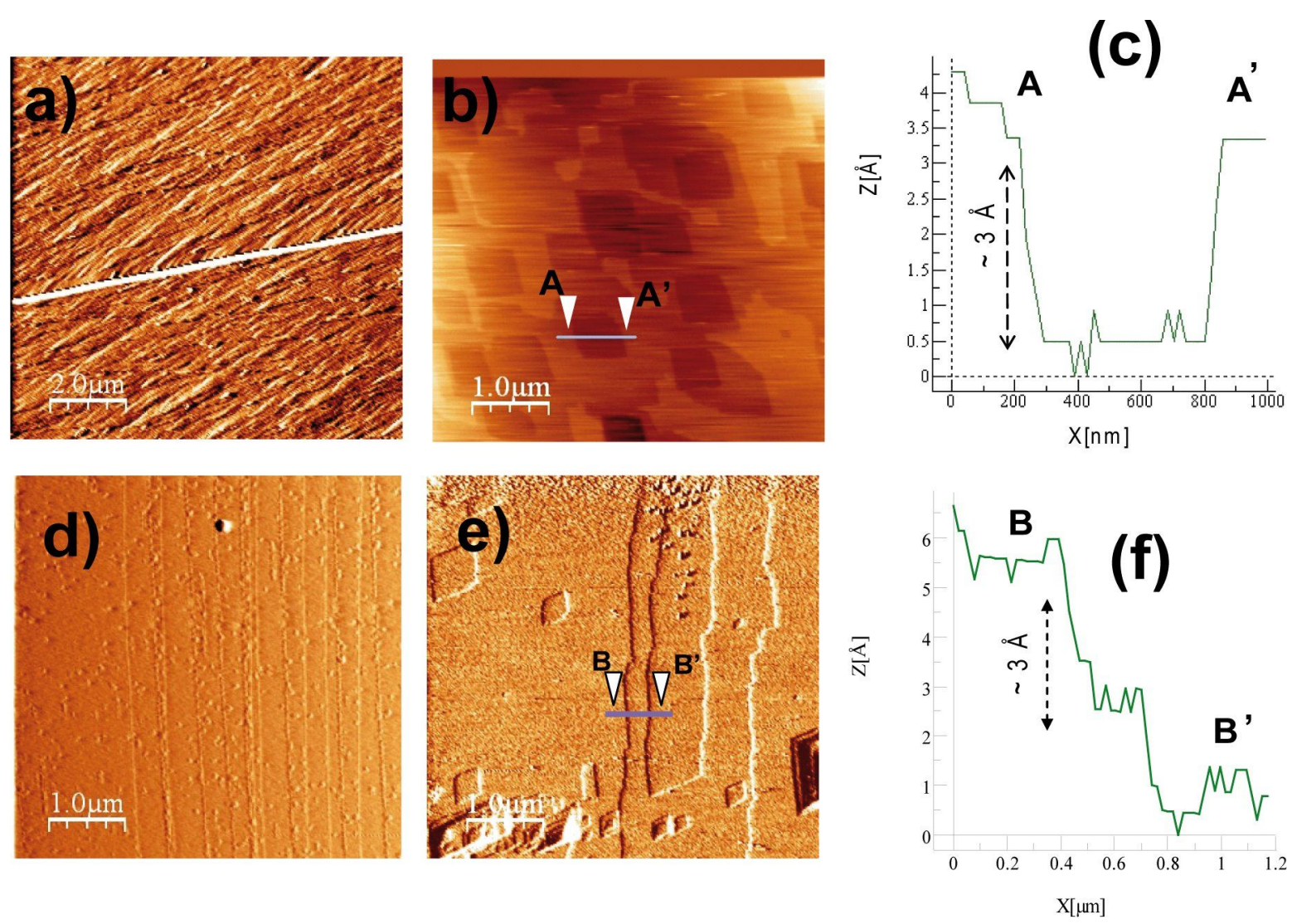

Figure 1: AFM deflection images of calcite cleavage surfaces. Top row: a) image in air shows the initial flat surface with a topographic variation that ranges over $2 \mathrm{~nm}$. The white line across the image corresponds to a terrace; b) same surface region with some drift after $300 \mathrm{~s}$ in Millipore MQ water showing a high density of etch pits homogeneously distributed and c) depth profile of an etch pit section. Bottom row: d) image in air shows the initial flat surface with a topographic variation that ranges over $4 \mathrm{~nm}$ and e) same surface region after $240 \mathrm{~s}$ in Millipore MQ water showing the random formation of etch pits and f) depth profile of a step edge section shown by the arrows in e).

\section{Results and Discussion \\ Dissolution of calcite}

Dissolution of the (104) calcite surface in Millipore MQ water was readily observed. Figure $1 \mathrm{~b}$ and Figure $1 \mathrm{c}$ show the formation of shallow (depth $\approx 0.3 \mathrm{~nm} \approx$ calcite unit cell) and deep rhombohedral etch pits all over the surface $[19,30,36,40]$. The ratio between the etch pit rhombus diagonals was $0.71 \pm 0.02$, which is similar to that reported by Pérez-Garrido et al. [41]. Etch pit merging and formation of trenches or steps were observed (Figure 1b and Figure 1e). The number of etch pits per square centimeter of surface $\left(N_{\text {pit }}\right)$ varied from $8 \times 10^{7}$ (only etch pits, Figure $1 \mathrm{~b}$ ) to $5 \times 10^{8}$ (etch pits and steps, Figure 1e) in scanned flat regions with similar initial roughness. The measured calcite dissolution rate, $R_{\mathrm{AFM}}$, was $1.45 \times 10^{-10} \mathrm{~mol} \cdot \mathrm{cm}^{-2} \cdot \mathrm{s}^{-1}$, which agrees with that at nearly neutral $\mathrm{pH}$ reported elsewhere $[19,42,43]$. The etch pit expansion rate, $R_{\mathrm{S}}$, was measured to be $1.82 \pm 0.12 \mathrm{~nm} \cdot \mathrm{s}^{-1}$ and falls within the range of those calculated for deionized water by Jordan and Rammensee (velocity of slow step $0.5 \pm 0.2 \mathrm{~nm} / \mathrm{s}$ and of fast steps $2.5 \pm 0.5 \mathrm{~nm} / \mathrm{s}$ ) [44].
Interaction between the acidic sulfate-rich solutions and the calcite cleavage surface (solution injected and not renewed) induced faster dissolution than in Millipore MQ water. A massive nucleation of new rhombohedral etch pits took place at $\mathrm{pH} 4.80$ after solution injection, in contrast to the fairly regular distribution of etch pits in Millipore MQ water (Figure 2). At $\mathrm{pH} 4.80 R_{\mathrm{AFM}}$ was $5.50 \times 10^{-10} \mathrm{~mol} \cdot \mathrm{cm}^{-2} \cdot \mathrm{s}^{-1}$, which is faster than that at $\mathrm{pH} 7$, and agrees with the expected rate at $\mathrm{pH} 5$ and $25^{\circ} \mathrm{C}[19]$.

In the experiments with $\mathrm{Na}_{2} \mathrm{SO}_{4}$ solution (Figure $3 \mathrm{a}$; solution injected and not renewed) the dissolution of the calcite cleavage surface was taking place such that equilibrium with respect to calcite was being approached. It was observed that the shape of newly formed rhombohedral etch pits was changing with time as the solution approached equilibrium with respect to calcite. The evolving shape was characterized by rounding of the obtuse-obtuse corner (Figure 3b-d). According to Teng et al. [45] and Teng [46] the retreat velocities of acute and obtuse steps do not show a linear dependence on supersaturation. In 


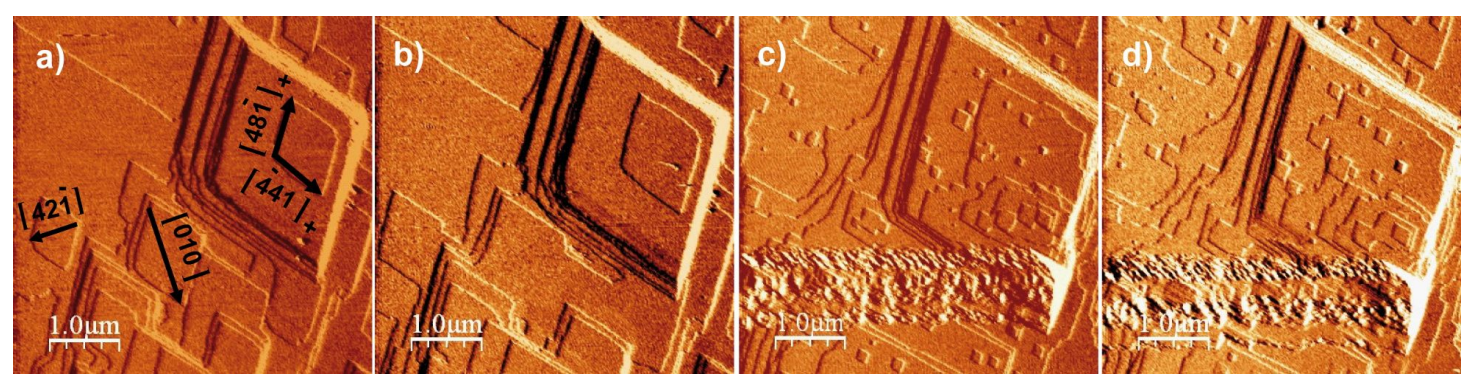

Figure 2: Sequential AFM deflection images of the reacted calcite (104) surface: initially in Millipore MQ water (a and b) and acid solution ( $\mathrm{pH} 4.80$ ) (c and d). Etch pits developed and spread. As $\mathrm{pH}$ was decreased to 4.80 , a large population of etch pits suddenly formed. Rhombohedra formed along the $[48 \overline{1}]^{+}$and $[\overline{4} 11]^{+}$directions with the long and short diagonals parallel to [010] and [42 $\left.\overline{1}\right]$, respectively.
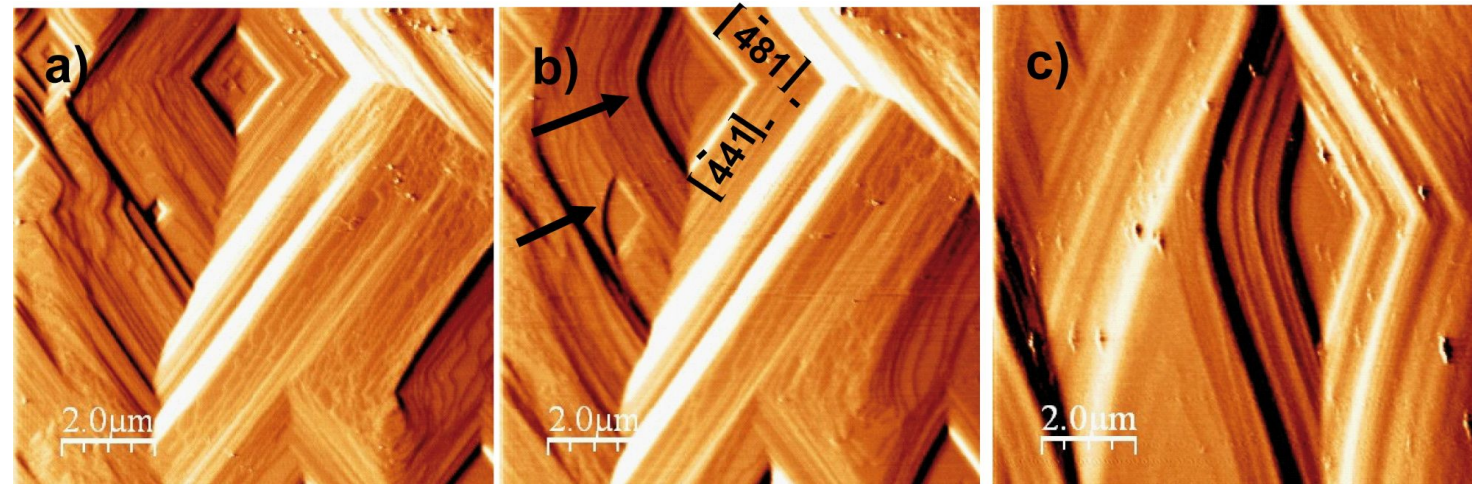

Figure 3: Sequential AFM deflection images of the reacted calcite cleavage surface in contact with $\mathrm{Na}_{2} \mathrm{SO}_{4}$ solution: a) characteristic morphology of rhombohedral etch pits (after acid injection, $\mathrm{pH} 4.08$ ) and b) rounding of the obtuse-obtuse corner of the rhombohedral etch pits (shown by arrows) after $12 \mathrm{~min}$, and c) rhombohedral etch pit with elongated shape after $43 \mathrm{~min}$ with a short/long diagonal ratio of $0.35 \pm 0.02$.

addition, several studies have shown that the velocities of acute and obtuse step spreading have different sensitivities to the solute activity ratios in the solution $[32,36,47]$. Calcite dissolution continuously took place during the solution saturation state drift. This implies a change in Gibbs energy along the experimental runs. As pointed out by Stipps et al. and de Leeuw et al. $[48,49]$ the observed distortion of the etch pit shape (Figure $3 \mathrm{~b}$ and Figure 3c) likely corresponds to an increase in the difference of velocities between obtuse and acute steps.

\section{Dissolution of dolomite}

Dolomite dissolution experiments were carried out similarly to those of calcite. First, dolomite dissolved in Millipore MQ water, and then, the reaction took place in sulfate-rich solutions at pH 2 and 3 (Table 1). Contrary to calcite dissolution, when dolomite reacted in Millipore MQ water, a nucleation of etch pits was not observed for approximately $25 \mathrm{~min}$. Only, at specific surface localities, step retreat was observed (Figure 4a), allowing the calculation of the retreat velocity $R_{\mathrm{S}}$, considered to be the average retreat velocity of non-crystallographically equivalent steps (Figure $4 \mathrm{~b}$ and Figure $4 \mathrm{c}$ ), which was $0.14 \pm 0.03 \mathrm{~nm} \cdot \mathrm{s}^{-1}$. This value is not far from the etch spreading rate of $0.09 \pm 0.01 \mathrm{~nm} \cdot \mathrm{s}^{-1}$ reported by Urosevic et al. [37] and is about one order of magnitude lower than the etch pit expansion rate of calcite obtained in this study.

As dolomite reacted in acid solution, etch pit nucleation of isolated etch pits was observed over the cleavage surface after $10 \mathrm{~min}$. Single etch pits presented an elongated rhombohedral shape (Figure 5a). As the surface kept dissolving for $8 \mathrm{~h}$, etch pit nucleation occurred all over the surface. Lack of sequential images for this long run prevented us from calculating $R_{\mathrm{AFM}}$ under acid conditions (Figure $5 \mathrm{~b}$ ). The formed etch pits showed the typical rhombohedral shape as expect from carbonate mineral dissolution [37].

\section{Coupled dissolution of calcite and dolomite and precipitation of gypsum}

As the calcite (104) cleavage surface reacted with the $\mathrm{pH} 2$ solution equilibrated with respect to gypsum, gypsum precipitation was readily observed (Figure 6). Micro-Raman analyses of the retrieved reacted samples confirmed the presence of gypsum. Gypsum nucleation took place uniformly all over the calcite surface immediately after the acid solution interacted 

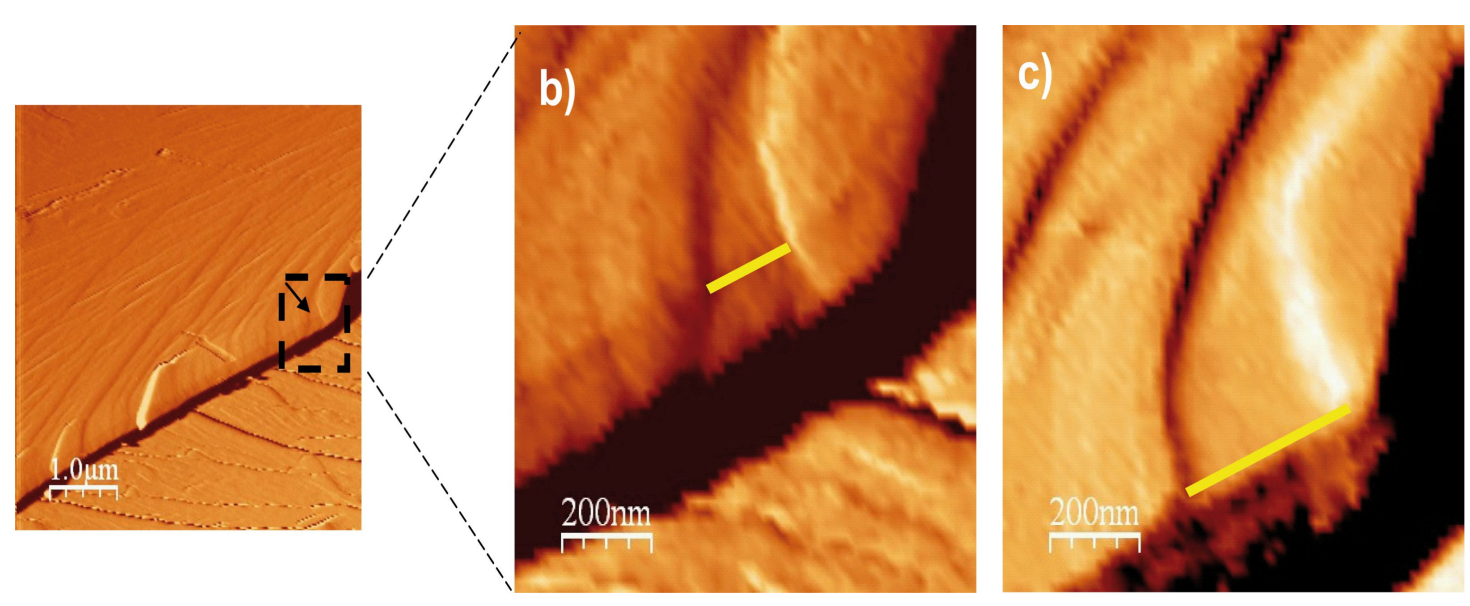

Figure 4: AFM deflection images of dolomite dissolution in Millipore MQ water: a) in air image of the dolomite (010) surface (exp. dol 1 in Table 1). Selected squared region in (a) to calculate the step-retreat rate based on the variation in length with time of the pointed terrace. The sequential images in b) and c) after 7.5 and 11.5 min respectively, show the consequent terrace evolution.

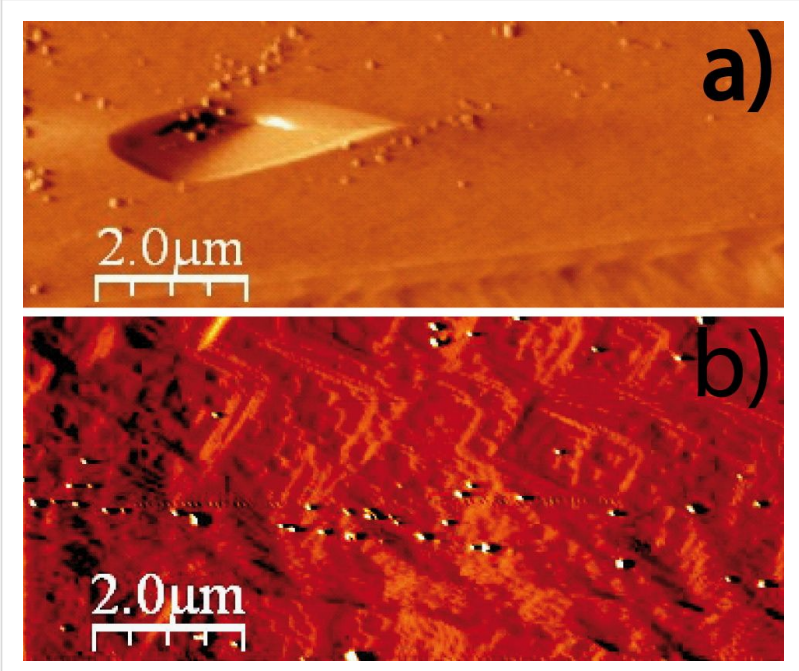

Figure 5: AFM deflection images of the reacted dolomite (104) cleavage surface in acid $\mathrm{Na}_{2} \mathrm{SO}_{4}$ solutions: a) after 10 min in $\mathrm{pH} 2$, isolated etch pits were observed and $\mathrm{b}$ ) in $\mathrm{pH} 3$, nucleation of etch pits was observed all over the surface after $8 \mathrm{~h}$. with the dissolving cleavage surface (Figure 6a and Figure 6b). At $\mathrm{pH} 2$, the gypsum precipitation induction time was slower than $100 \mathrm{~s}$ (time between two sequential image captures). The epitaxially grown gypsum crystals displayed an elongated (arrow-like) shape, consistent with their crystallographic monoclinic form, usually presented as tabular crystals, with the long and short sides parallel to the calcite $[\overline{4} 41]$ and [48 $\overline{1}]$ directions, respectively (Figure 6a and Figure 6c).

This crystal morphology was observed by Booth et al. [18]. 3-D images of the arrow-shaped gypsum crystals showed that the formed gypsum crystals, which entirely coated the cleavage surface, were slightly tilted (ca. $1^{\circ}$ ) with respect to the calcite (104) cleavage surface. The lack of a reference surface on the calcite substrate and the fast-formed gypsum coating prevented the calculation of gypsum growth rates at the $\mathrm{pH}$ range studied. Gypsum precipitation ceased as Ca release from calcite dissolution stopped. This was most likely because calcite dissolution stopped as either the entire calcite surface was totally passi-

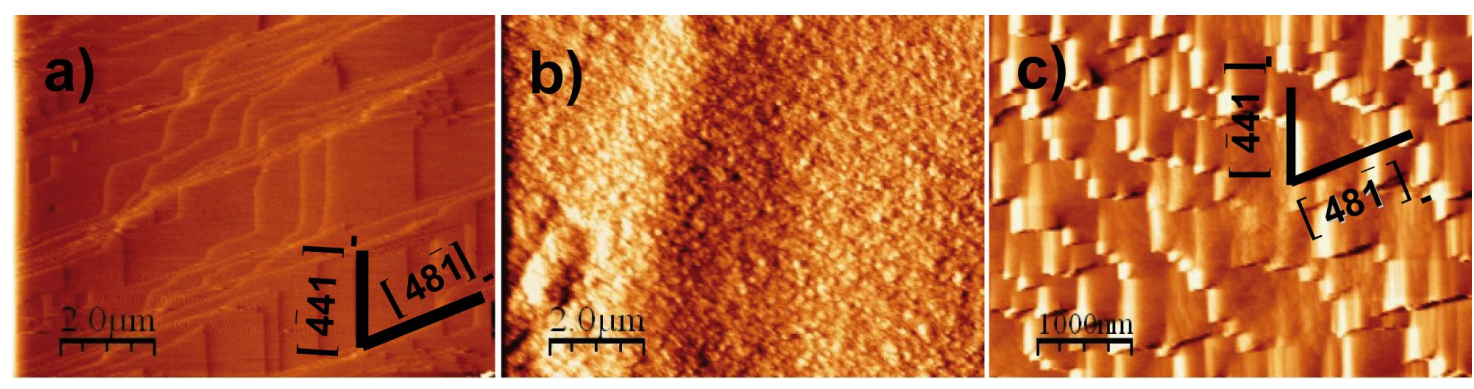

Figure 6: AFM deflection images of reacting (104) calcite surface: a) dissolution in Millipore MQ water; b) after injecting a solution in equilibrium with gypsum at $\mathrm{pH} 2.18$, gypsum precipitation starts (1.5 min) and c) gypsum arrows grow laterally and coalesce (41 min). 
vated impeding ion release through the gypsum layer, or because equilibrium with respect to calcite was achieved.

In experiments in which calcite dissolved at $\mathrm{pH} \geq 3$ in gypsum equilibrated solutions, the gypsum induction time was longer than $240 \mathrm{~s}$, indicating slower gypsum growth than that at $\mathrm{pH} 2$ due to slower calcite dissolution. Gypsum also grew epitaxially over the entire surface and, in general, the crystals showed the arrow-like shape (Figure $7 \mathrm{a}$ ). In some $\mathrm{Na}_{2} \mathrm{SO}_{4}$ experiments, however, gypsum precipitation occurred non-uniformly over the cleavage surface, taking place at specific localities, mostly at step edges, and forming individual protuberances (spikes), equilibrated with gypsum

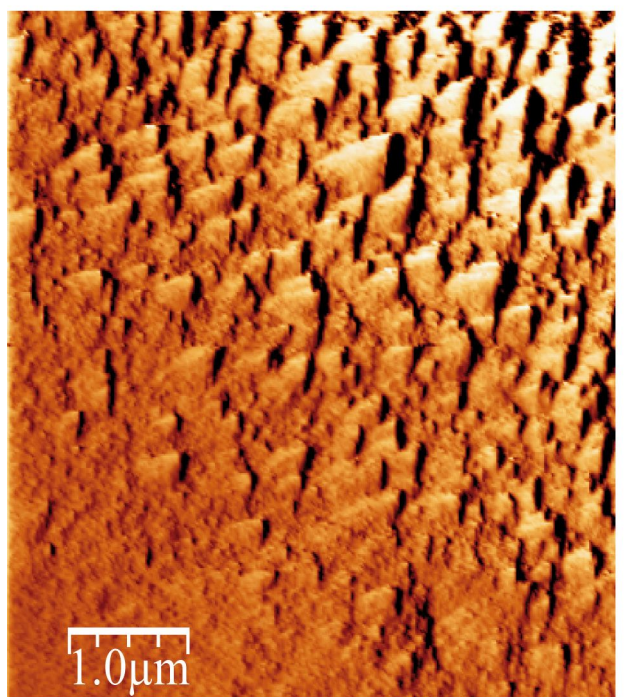

$124 \min$
$\mathrm{Na}_{2} \mathrm{SO}_{4}$

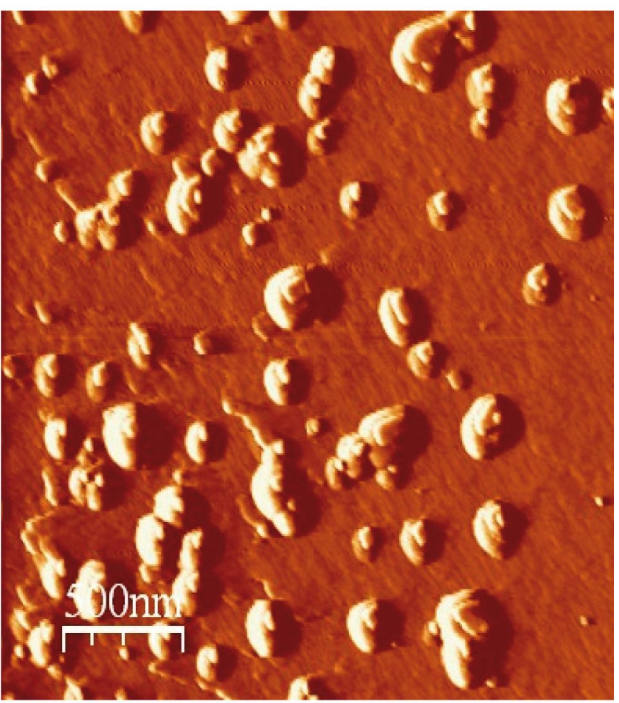

$152 \mathrm{~min}$

Figure 7: Gypsum precipitation on a calcite surface at $\mathrm{pH}$ 3: a) Experiment with gypsum equilibrated $\mathrm{CaSO}_{4}$ solution: homogeneous, arrow-type gypsum growth on the cleavage calcite surface; b) Experiment with $\mathrm{Na}_{2} \mathrm{SO}_{4}$ solution: random protuberances over the calcite surface.

a)

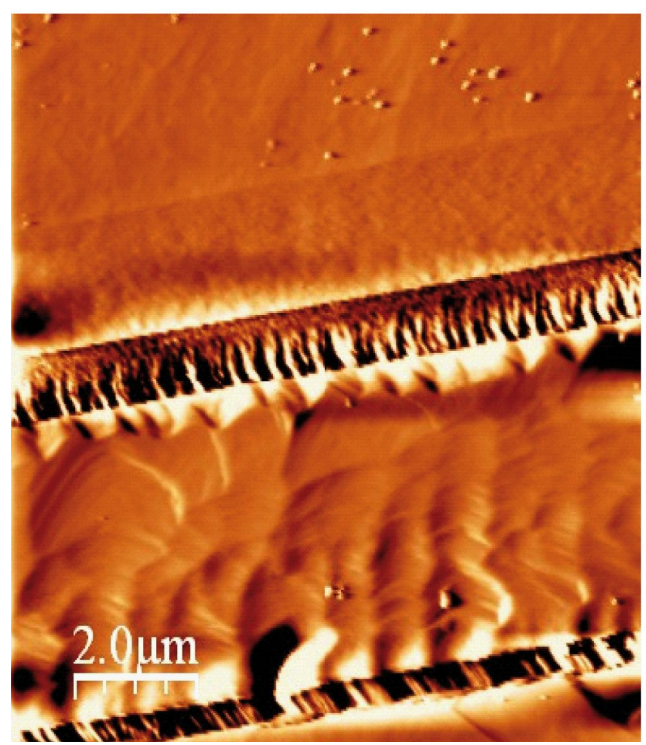

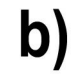

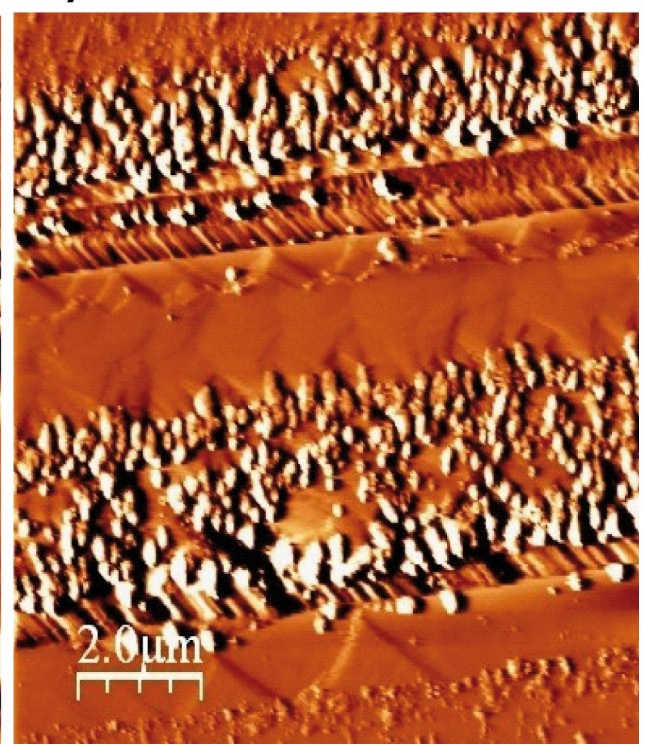

Figure 8: Sequential AFM deflection images of reacted dolomite surface in $\mathrm{pH} 3\left(\mathrm{H}_{2} \mathrm{SO}_{4}\right)$ in solution equilibrated with respect to gypsum: a) after $4 \mathrm{~h}$, shallow and deep etch pits are visible on the dolomite surface and b) after $6 \mathrm{~h}$, gypsum precipitated mainly along the step edges. 
suggesting preferential sites for the formation of these nuclei (Figure 7b).

When the cleaved dolomite surface was the substrate, gypsum precipitation from dolomite dissolution was slower than that from calcite dissolution at the same $\mathrm{pH}$. Micro-Raman analyses of the reacted fragments at $\mathrm{pH} 2$ and 3 confirmed precipitated gypsum at the dolomite cleavage surfaces. Gypsum precipitation occurred on the previously etch pitted dolomite surface after about $6 \mathrm{~h}$, and again it was difficult to establish an induction time. Epitaxial growth was observed to be non-uniform over the surface (Figure 8), taking place on preferential surface regions, such as step and terrace edges, and areas with marked roughness. This behavior suggests that gypsum precipitation on dolomite cleavage surfaces was favored at highly reactive surface regions, where dolomite dissolution and hence element release was highest. After $8 \mathrm{~h}$ of reaction time, dolomite passivation was still only partial with etch pitted regions still visible, in contrast to the full gypsum armoring on the calcite surface.

\section{Conclusion}

In-situ atomic force microscopy was used to investigate the coupled processes of carbonate mineral dissolution and gypsum precipitation in acid sulfate-rich solutions in solutions both undersaturated and in equilibrium with respect to gypsum at room temperature.

Dissolution of calcite and dolomite occurred forming the characteristic rhombohedral etch pits. Calcite dissolution rates measured at nearly neutral $\mathrm{pH}$ and $\mathrm{pH}$ of 4.80 agreed with VSImeasured rates [19]. The calcite etch pit expansion rate and the dolomite step retreat velocity were calculated in near neutral $\mathrm{pH}$ (Millipore MQ water), the latter being about one order of magnitude lower than the former. Precipitation occurred as a result of the carbonate mineral dissolution. Therefore, as in acidic $\mathrm{pH}$ conditions calcite dissolution rates were faster than those of dolomite, gypsum precipitation was correspondingly faster in the calcite dissolution experiments. Epitaxial growth was the growth mechanism as observed by Booth et al. [18], and gypsum nucleation induction times were shorter in the calcite dissolution experiments. In the case of calcite dissolution in gypsum-equilibrated solutions, gypsum nucleation occurred immediately and surface coating was uniform all over the calcite surface, yielding a total calcite passivation. Arrowshaped gypsum crystals evolved along the etch pit crystallographic directions ([ $\overline{4} 41]$ and $[48 \overline{1}])$. In $\mathrm{Na}_{2} \mathrm{SO}_{4}$ solutions undersaturated with respect to gypsum, precipitation occurred via the formation of isolated growth protuberances randomly distributed over the cleavage surface. In the case of dolomite dissolution in gypsum-equilibrated solutions, gypsum precipitation was favored at highly reactive surface regions (step and terrace edges) and rough regions. Gypsum partially coated the dolomite surface during the experimental runs.

In all experiments gypsum precipitation resulted from a twostep process: 1 . The calcite or dolomite dissolved, as observed in the regular formation of rhombohedral etch pits and step retreat, thereby releasing $\mathrm{Ca}^{2+}$ or $\mathrm{Ca}^{2+}$ and $\mathrm{Mg}^{2+}$ ions to solution. 2. The solution at the mineral-solution interface became supersaturated with respect to gypsum, which then precipitated. These two processes were coupled at the interface and continued as long as $\mathrm{Ca}^{2+}$ was being released.

\section{Acknowledgements}

This work was partially funded by project CGL2010-20984C02-01 from the Spanish Government and the EU initial training network Delta-Min (Mechanisms of mineral replacement reactions, Grant PITN-GA-2008-215360). FGO was supported by a JAE-Predoc grant under the Program "Junta para la Ampliación de Estudios". We would like to thank Veronika Rapelius (Münster University) for laboratory assistance and Tariq Jawhari Colin (Centres Científics i Tecnològics Barcelona University) for assistance during the micro-Raman measurements. Ignasi Casanova (Polytechnic University of Catalonia) and Encarnación Ruiz Agudo (Department of Mineralogy and Petrology, University of Granada) are thanked for the assistance during AFM measurements.

\section{References}

1. Hedin, R. S.; Watzlaf, G. R.; Nairn, R. W. J. Environ. Manage. 1994, 23, 1338-1345.

2. Kleinmann, R. L. P.; Hedin, R. S.; Nairn, R. W. Treatment of mine drainage by anoxic limestone drains and constructed wetlands. In Acidic Mining Lakes; Geller, W.; Klapper, H.; Salomons, W., Eds.; Springer: Berlin, Germany, 1998; pp 303-319. doi:10.1007/978-3-642-71954-7_16

3. Cravotta, C. A., III; Trahan, M. K. Appl. Geochem. 1999, 14, 581-606. doi:10.1016/S0883-2927(98)00066-3

4. Cravotta, C. A. J. Environ. Qual. 2003, 32, 1277-1289. doi:10.2134/jeq2003.1277

5. Johnson, D. B.; Hallberg, K. B. Sci. Total Environ. 2005, 338, 3-14. doi:10.1016/j.scitotenv.2004.09.002

6. Putnis, A. Mineral. Mag. 2002, 66, 689-708. doi:10.1180/0026461026650056

7. Putnis, A.; Putnis, C. V. J. Solid State Chem. 2007, 180, 1783-1786. doi:10.1016/j.jssc.2007.03.023

8. Putnis, C. V.; Ruiz-Agudo, E. Elements 2013, 9, 177-182. doi:10.2113/gselements.9.3.177

9. Pearson, F. H.; McDonnell, A. J. J. Environ. Eng. Div. (Am. Soc. Civ. Eng.) 1975, 101, 139-158.

10. Santoro, L.; Valpolicelli, G.; Caprio, V. Water Res. 1987, 21, 641-647. doi:10.1016/0043-1354(87)90074-1

11. Wilkins, S. J.; Compton, R. G.; Taylor, M. A.; Viles, H. A. J. Colloid Interface Sci. 2001, 236, 354-361. doi:10.1006/jcis.2000.7418 
12. Hammarstrom, J.; Sibrell, P. L.; Belkin, H. E. Appl. Geochem. 2003, 18, 1705-1721. doi:10.1016/S0883-2927(03)00105-7

13. Watzlaf, G. R.; Schroeder, K. T.; Kleinmann, R. L. P.; Kairies, C. L.; Nairn, R. W.; Street, W. B. The passive treatment of Coal Mine Drainage. U.S. Department of Energy DOE/NET-2004/1202; National Technical Information Service: Springfield, VA, USA, 2004; pp 1-72.

14. Soler, J. M.; Boi, M.; Mogollon, J. L.; Cama, J.; Ayora, C.; Nico, P. S.; Tamura, N.; Kunz, M. Appl. Geochem. 2008, 23, 3579-3588. doi:10.1016/j.apgeochem.2008.08.011

15. Offeddu, F. G.; Cama, J.; Soler, J. M.; Ayora, C. Geochim. Cosmochim. Acta 2009, 73, A964.

16. Offeddu, F. G.; Cama, J.; Soler, J.; Ganor, J.; Casanova, I.; Putnis, C. V.; Putnis, A. Macla 2011, 15, 155-156.

17. Huminicki, D. M. C.; Rimstidt, J. D. Appl. Geochem. 2009, 24 , 1626-1634. doi:10.1016/j.apgeochem.2009.04.032

18. Booth, J.; Hong, Q.; Compton, R. G.; Prout, K.; Payne, R. M. J. Colloid Interface Sci. 1997, 192, 207-214. doi:10.1006/jcis.1997.4978

19. Atanassova, R.; Cama, J.; Soler, J. M.; Offeddu, F. G.; Queralt, I. Eur. J. Mineral. 2013, 25, 331-351.

20. Dávila, G.; Luquot, L.; Cama, J.; Soler, J. Interaction between the Hontomín cap rock and $\mathrm{CO}_{2}$-rich brine during geological $\mathrm{CO}_{2}$ sequestration. In Proceedings of European Mineralogical Congress, Frankfurt, Germany, Sept 2-6, 2012; 2012.

21. García-Rios, M.; Luquot, L.; Soler, J. M.; Cama, J. Procedia Earth Planet. Sci. 2013, 7, 109-112. doi:10.1016/j.proeps.2013.03.013

22. García-Rios, M.; Dávila, G.; Offeddu, F. G.; Soler, J. M.; Cama, J. Macla 2011, 15, 93-94.

23. Kloppmann, W.; Bromblet, P.; Vallet, J. M.; Vergès-Belmin, V.; Rolland, O.; Guerrot, C.; Gosselin, C. Sci. Total Environ. 2011, 409, 1658-1669. doi:10.1016/j.scitotenv.2011.01.008

24. Sánchez, J. S.; Romaní, J. R. V.; Alves, C. Constr. Build. Mater. 2011, 25, 813-822. doi:10.1016/j.conbuildmat.2010.07.001

25. Walker, R. A.; Wilson, K.; Lee, A. F.; Woodford, J.; Grassian, V. H.; Baltrusaitis, J.; Rubasinghege, G.; Cibin, G.; Dent, A. Sci. Rep. 2012, 2, No. 880. doi:10.1038/srep00880

26. Bard, F.; Bilal, E. Carpathian J. Earth Environ. Sci. 2011, 6, 241-250.

27. Hillner, P. E.; Manne, S.; Gratz, A. J.; Hansma, P. K. Ultramicroscopy 1992, 44, 1387-1393.

28. Shindo, H.; Ohashi, M. Appl. Phys. A 1998, 66, S487-S490. doi:10.1007/s003390051188

29. Arvidson, R. S.; Collier, M.; Davis, K. J.; Vinson, M. D.; Amonette, J. E.; Luttge, A. Geochim. Cosmochim. Acta 2006, 70, 583-594. doi:10.1016/j.gca.2005.10.005

30. Harstad, A. O.; Stipp, S. L. S. Geochim. Cosmochim. Acta 2007, 71, 56-70. doi:10.1016/j.gca.2006.07.037

31. Astilleros, J. M.; Fernández-Díaz, L.; Putnis, A. Chem. Geol. 2010, 271, 52-58. doi:10.1016/j.chemgeo.2009.12.011

32. Larsen, K.; Bechgaard, K.; Stipp, S. L. S. Geochim. Cosmochim. Acta 2010, 74, 2099-2109. doi:10.1016/j.gca.2009.12.028

33. Ruiz-Agudo, E.; Kowacz, M.; Putnis, V. C.; Putnis, A. Geochim. Cosmochim. Acta 2010, 74, 1256-1267. doi:10.1016/j.gca.2009.11.004

34. Pina, C. M.; Pimentel, C.; García-Merino, M. Surf. Sci. 2010, 604, 1877-1881. doi:10.1016/j.susc.2010.07.019

35. Hövelmann, J.; Putnis, C. V.; Ruiz-Agudo, E.; Austrheim, H. Environ. Sci. Technol. 2012, 46, 5253-5260. doi:10.1021/es300403n

36. Ruiz-Agudo, E.; Putnis, C. V. Mineral. Mag. 2012, 76, 227-253. doi:10.1180/minmag.2012.076.1.227
37. Urosevic, M.; Rodriguez-Navarro, C.; Putnis, C. V.; Cardell, C.; Putnis, A.; Ruiz-Agudo, E. Geochim. Cosmochim. Acta 2012, 80, 1-13. doi:10.1016/j.gca.2011.11.036

38. Horcas, I.; Fernández, R.; Gómez-Rodríguez, J. M.; Colchero, J.; Gómez-Herrero, J.; Baro, A. M. Rev. Sci. Instrum. 2007, 78, 013705. doi:10.1063/1.2432410

39. Parkhurst, D. L.; Appelo, C. A. J. User's guide to PHREEQC (Version 2). Water-Resources Investigations Report 99-4259; U.S. Geological Survery Publications, 1999.

40. MacInnis, I. N.; Brantley, S. L. Geochim. Cosmochim. Acta 1992, 56, 1113-1126. doi:10.1016/0016-7037(92)90049-O

41. Pérez-Garrido, C.; Fernández-Díaz, L.; Pina, C. M.; Prieto, M. Surf. Sci. 2007, 601, 5499-5509. doi:10.1016/j.susc.2007.09.021

42. De Giudici, G. Am. Mineral. 2002, 87, 1279-1285.

43. Duckworth, O. W.; Martin, S. Am. Mineral. 2004, 89, 554-563.

44. Jordan, G.; Rammensee, W. Geochim. Cosmochim. Acta 1998, 62, 941-947. doi:10.1016/S0016-7037(98)00030-1

45. Teng, H. H.; Dove, P. M.; DeYoreo, J. J. Geochim. Cosmochim. Acta 1999, 63, 2507-2512. doi:10.1016/S0016-7037(99)00103-9

46. Teng, H. H. Geochim. Cosmochim. Acta 2004, 68, 253-262. doi:10.1016/S0016-7037(03)00423-X

47. Stack, A. G.; Grantham, M. C. Cryst. Growth Des. 2010, 10 , 1409-1413. doi:10.1021/cg901395z

48. Stipp, S. L. S.; Eggleston, C. M.; Nielsen, B. S. Geochim. Cosmochim. Acta 1994, 58, 3023-3033. doi:10.1016/0016-7037(94)90176-7

49. de Leeuw, N. H.; Parker, S. C.; Harding, J. H. Phys. Rev. B 1999, 60, 13792-13799. doi:10.1103/PhysRevB.60.13792

\section{License and Terms}

This is an Open Access article under the terms of the Creative Commons Attribution License (http://creativecommons.org/licenses/by/2.0), which permits unrestricted use, distribution, and reproduction in any medium, provided the original work is properly cited.

The license is subject to the Beilstein Journal of Nanotechnology terms and conditions: (http://www.beilstein-journals.org/bjnano)

The definitive version of this article is the electronic one which can be found at: doi:10.3762/bjnano.5.138 